\title{
ウェアラブルコンピュータの現状と産業分野への応用
}

\section{The Present State of Wearable Computer and its Industrial Applications}

\author{
Masakatsu Kourogi \\ National Institute of Advanced Industrial Science and \\ Technology (AIST), Intelligent Systems Institute
}

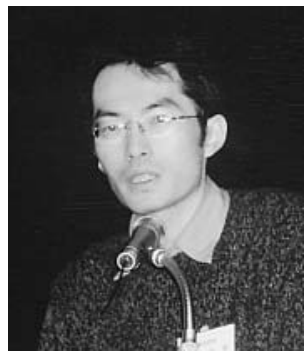

The term "Wearable computing" is now widespread in general thanks to the media presence.

In this paper, I define the term of "Wearable computer" and discuss its crucial components, which are displays, input interfaces and sensing devices and technologies. As one of sensing technologies, overview of a personal positioning method proposed by the authors is described. Lastly, the potential applications to industry are described.

分類： $V_{1}$ 計装・制御システム一般， $Y_{0}$ その他

\section{1. ウェアラブルコンピュータ}

近年，ウェアラブルコンピュータという用語が論文 中の学術用語としてのみならず, 新聞や雑誌の記事な どのメディアにも登場するようになった（図 1)。こ の用語は, 直訳すれば, 着用可能な計算機という意味 になるが，これは何を指しているのであろうか。

\section{1 用語の定義}

一般的な認識はさておき, 学術的には,「常時作動 する着用 (もしくは携帯) 可能な計算機」として定義 するのが妥当だと思われる ${ }^{122)}$ 。したがって，持ち運ん でいる間は動作していないラップトップ型コンピュー タやPDA などはウェアラブルコンピュータとは言え ない。一方で，携帯電話などは常に動作しており，ま た携帯されていることから， ウェアラブルコンピュー 夕の一種であると見なすことができる。健康器具の一
つである歩数計もその常時動作性・着用性からウェア ラブルコンピュータの一種であると見ることができ， また前述の携帯電話との親和性も高い。

\section{2 計算機を着用・常時作動させることの意義}

さて，ここでウェアラブルコンピュータの実用的な 側面を考えてみる。すなわち計算機を着用し, 常時作 動させることの利点はどこにあるだろうか？ PDA やラップトップ型コンピュータにはできなくて, ウェ アラブルコンピュータにできることとは何であろう か?

最も重要な点は, 常時動作していることによって, 利用者の状態（寝ているのか, 起きているのか, 歩い ているのか，読書しているのか，など）を逐一認識し， その結果に基づいて利用者の指示を仰ぐことなく，能 動的（アクティブ）に動作することが可能となること である。 


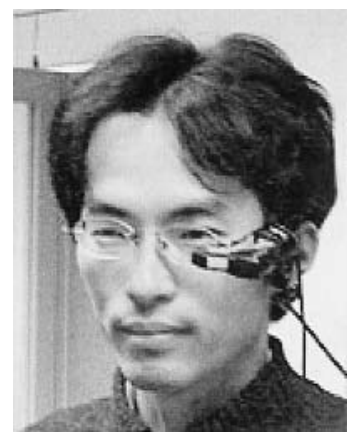

図１ウェアラブルコンピュータユーザの外観例

例えば，家を出発するときに，郵便物を出すことを 計算機に入力したとする。すると，郵便ポストを通過 したときに，利用者はそのことを忘れていても， ウェ アラブルコンピュータが「郵便物は出さなくてよいの ですか？」とアシストしてくれる，という具合である。 このように, ウェアラブルコンピュータは日常生活を より豊かに生産的なものとする上で,

大きな可能性を持っている。

\section{3 ウェアラブルコンピュータを構成する}

\section{要素技術}

ウェアラブルコンピュータを構成するためには, 単 に計算機を身に着けるだけでは十分ではない。重要な 構成要素として, ディスプレイ, 入出力インタフェー ス, センシング技術の 3 つが挙げられる。以下, 各構 成要素について述べ，特に筆者らが研究を進めている センシング技術の一つであるパーソナルポジショニン グについて述べる。

\section{4 拡張現実感 (Augmented Reality)}

拡張現実感とは, 実世界に対する人間の感覚及び知 覚 (例えば視覚) を計算機の能力を借りてょり強化す る技術の総称である。例えば，工場に配置された配電 盤を見て各部品が何に対応しているか，ウェアラブル ディスプレイ上に重畳表示することで，利用者の能力 を増強することができる。この技術はその性質上，ウ エアラブルコンピュータとの親和性が高いと考えられ る。文献 ${ }^{3}$ は，拡張現実感に関するサーベイに詳しい。

\section{2. ディスプレイ}

ウェアラブルコンピュータのディスプレイは，その 用途に応じて，大きく二つに分類される。まず,1）常 時すばやく見ることができるものと,2）必要に応じて 取り出して見れば十分なものとに分かれる。後者は基 本的には PDA や携帯電話，または腕時計のような表 示装置で十分であるが，前者は利用者の頭部もしくは
その付近に常時装着されている必要があり, 装置には 特別な工夫が必要である。後者の応用例は実時間性を 要求しない情報提示などであり, 頭部への装着は必ず しも必要ではない。

\section{1 透過型ディスプレイ}

これは, 実際に物理的に見えている投影像の上にデ イスプレイ装置の映像を重畳表示する装置である。視 界を遮らないという長所がある反面, 重畳される映像 及び視界が比較的暗くなるという短所がある。また， 前述の拡張現実感のような応用例においては，実世界 の物体に計算機が生成した CG などを重畳表示する場 合, わずかな位置ずれであっても人間の視覚には感知 されてしまうため, 計算機側には低遅延で高速な処理 が必要となる。

\section{2 映像投影型ディスプレイ}

これは, ディスプレイ装置の映像のみを利用者が観 るタイプのもので, フルフェイスタイプと, それ以外 に分類される。フルフェイスタイプの映像投影型ウェ アラブルディスプレイにおいては, 利用者の視界すべ てを生成するため，実世界における物理的な運動と映 像の変化との不整合は，乗物酔い (motion sickness) のような症状を引き起こすことがあり, 運用には注意 が必要である。ところで, 前述の拡張現実感のような 応用例に対しては, 計算機側の負荷は小さい。ディス プレイに出力する映像上で，物体と CG との位置合わ せさえ正しければよいからである。

\section{3 現在入手可能なウェアラブルディスプレイ}

現時点で商用ベースで入手可能な製品は, 主として, 米国の MicroOptical 社 ${ }^{4}$ が製造しているもの，国内で は島津製作所 ${ }^{5}$ の製作している Data Glass シリーズが 有名である。他にもパーソナルユース向けの映像観賞 装置としてのウェアラブルディスプレイは存在する。

\section{3. 入カインタフェース}

ウェアラブルコンピュータを有効に活用するために は，人間にとって使いやすい入力インタフェースが欠 かせない( ${ }^{6}$ 。ウェアラブルコンピュータへの入力を実 現するインタフェースはその性質上，手または指で容 易に操作可能なものでなくてはならない。

\section{1 デバイスタイプの入カインタフェース}

現在利用可能な入力インタフェースとしては，親指 と人差指で操作するハンディトラックボールや, 米国 の Handkey ${ }^{7)}$ の製品であり，文字入力とマウスのポイ ンティング等が可能な Twiddler が有名である。また， 研究・試作段階ではあるが, NTTドコモの福本らが 開発した指装着型のタッピングデバイス ${ }^{8}$ が有名であ 
る。

\section{2 仮想タイプの入カインタフェース}

利用者視点の映像を撮影するカメラが装着されてい ることを前提とすると，そのカメラの前で手指をかざ して動かすことでポインティング，クリッキングを実 現するハンドジェスチャ入力インタフェースを実現す ることが可能となる 9)。カメラを装着することが必 須な応用例においては, 非常に有効な入力インタフェ ースの一つであると考えられる。

\section{4. センシング技術}

ウェアラブルコンピュータが有効に活用できるため には，利用者の外界と内部（すなわち利用者の状態） をセンシングできる必要がある。

\section{1 物理量のセンシング技術}

最もシンプルでかつ重要なセンシング対象は利用者 の位置・方位を表す物理量であろう。このセンシング 技術には大きく分けて二つある。インフラ側に超音波 または磁場などを発生または受信する装置がある夕イ プであり，インフラ装置の適用範囲でしか動作しない。 しかし, 精度は一定範囲に保証されており, 安定した 動作が期待できる。狭い範囲で十分な精度の位置・姿 勢を取得する応用例（拡張現実感など）とはうまく融 合する。もう一つは自律型の慣性センサ群による技術 である。非常に高精度な角速度センサ（例えば光ファ イバジャイロセンサ）と加速度センサを組み合わせて， 装置（Inertial Measurement Unit：IMU と呼ばれる) の現在の位置・姿勢を取得する技術である。航空機や 潜水艦などにはすでに配備されており, 実用化されて いる。しかしながら, 小型化, 低価格化は進まず, ウ エアラブルコンピュータ向けの用途には不向きである。 以下の章では, 筆者らが提案するウェアラブルコンピ ユータ向けの位置・方位取得手法の概要を述べる。

\section{2 その他のセンシング技術}

利用者の生体センサ情報（発汗量や心拍数, 脳波) などを捉えることは，利用者の状態を知る上で非常に 有効な技術となろう。利用者が現在食事をしているの か, 歩いているのか, 階段を昇っているのか, など, 生体信号から取得することができる可能性がある。ま た, 特定の化学物質（気体）を検出するセンサは, 生 命を脅かす危険性のある物質の検出など, 危険な作業 現場においては不可欠なものであろう。

\section{5. パーソナルポジショニング}

筆者らは, 利用者視点の映像を撮影するカメラと頭 部装着型慣性センサ, 頭部装着型ディスプレイ, 腰部
装着型歩行動作検出・計測センサに基づいてパーソナ ルポジショニングを実現し, その応用例として拡張現 実システムを構築した。

\section{1 ビジョン（画像）に基づくパーソナル ポジショニング}

筆者らは, 1999 年よりウェアラブルなビジュアルイ ンタフェースの研究に取り組んできた ${ }^{10)}$ 。その過程に おいて, パノラマ画像群を情報源に用いた位置・方位 取得および注釈提示手法（パノラマベーストアノテー ション）を提案した(1112)。この手法は, ウェアラブル コンピュータの利用者を想定していて, その利用者視 点の入力画像と事前に撮影された画像群（撮影位置 · 方位は既知）を情報源として用いている。その概要を 図 2 に示す。

\section{2 歩行動作検出・計測に基づくパーソナル ポジショニング}

次に, 筆者らは, 人間 (歩行者) の移動量を歩行動 作検出・計測に基づいて推測するアプローチを導入し た。すなわち，人間が歩行によって移動するときに現 われる物理的なパターンを検出し，これに基づいて基 準位置・方位からの相対移動量を推定する（一種の dead-reckoning である) アプローチである。人間の 歩行動作は重心位置の鉛直方向及び進行方向の加速度 変化の典型的なパターンとして現われる。

図 3 に典型的な加速度成分（鉛直方向・進行方向） のパターンの一つを示す。このパターン検出を腰部に 装着されたセンサ群（加速度・角速度・磁気センサ） を用いて处理する。同時に, 利用者の進行方向を角速 度の積算と地磁気を捕捉する磁気センサをカルマンフ

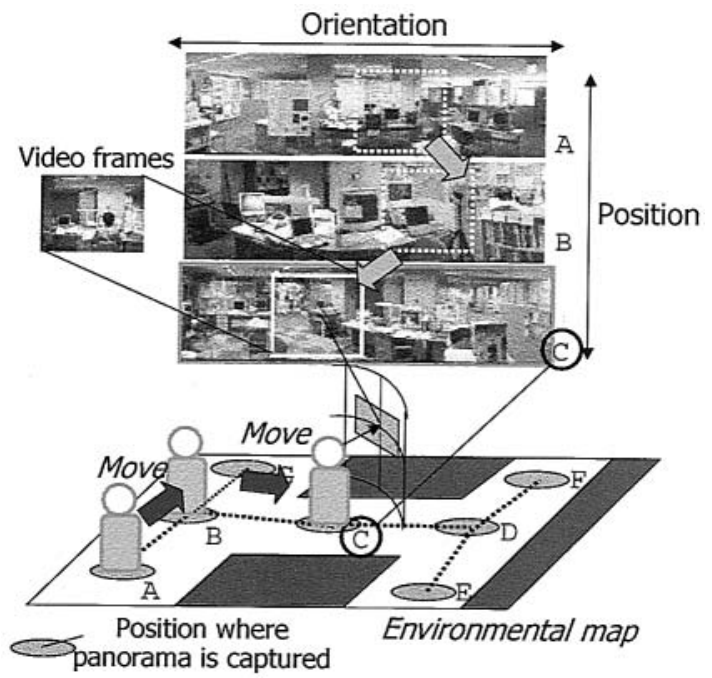

図 2 パノラマペーストアノテーション 
イルタの枠組で統合することによって推定することで, 利用者の進行方向をロバストに取得する ${ }^{13)}$ 。また, こ れらのセンサ群を用いて歩行速度の推定，階段の昇降， エレベータ昇降の動作検出も可能とした ${ }^{14)}$ 。

相対移動量をビジョンとは独立して検出することが

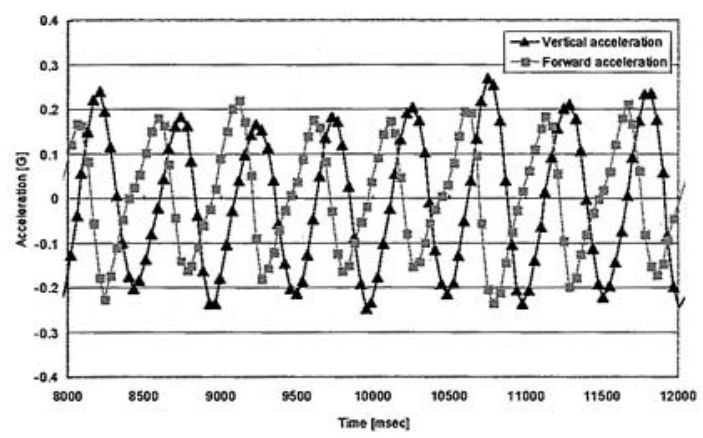

図 3 典型的な加速度成分 (鉛直 - 進行方向) パ夕 ーン
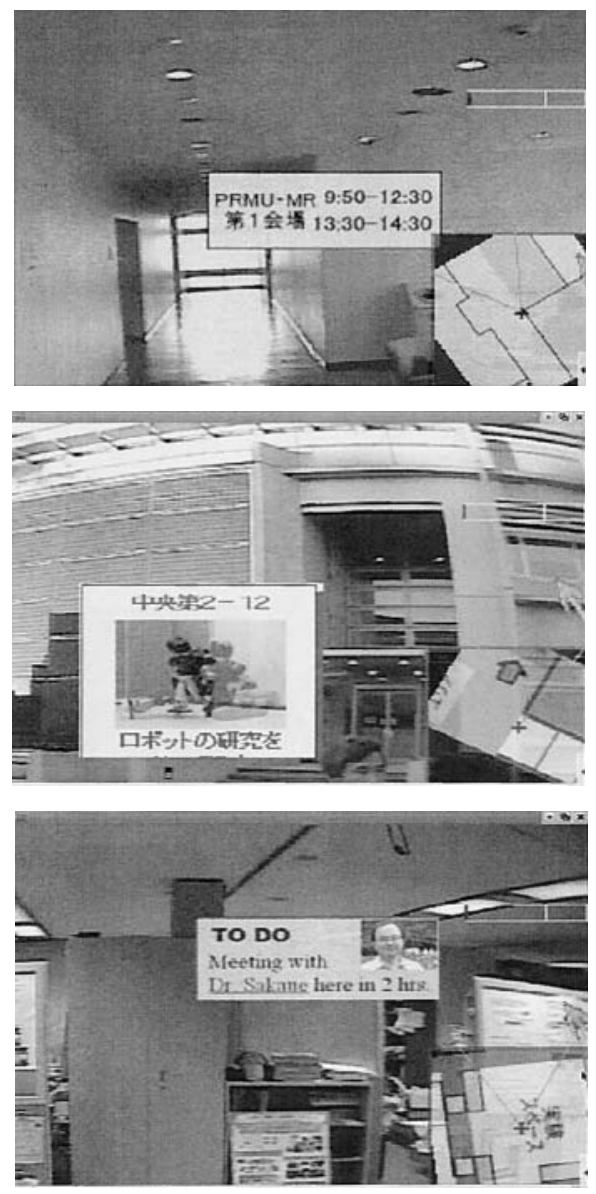

図 4 パーソナルポジショニングに基づく拡張現 実システムの出力画像
可能となったため，入力画像は常にパノラマ画像群と 位置合わせする必要はなくなり, 計算コストは大幅に 削減された。また，本手法 ${ }^{14)}$ は $30 \mathrm{~m}$ の歩行移動距離 につき $1 \mathrm{~m}$ 程度の誤差累積しか生じないため, 必要 となる画像群 (パノラマ画像である必要はない) は 1 /100 程度に削減できる。このため, 本パーソナルポ ジショニングシステムでは, ウェアラブル PC 単体で 動作させることが可能となった。

図 4 にパーソナルポジショニングシステムに基づい た, 拡張現実感の応用例（実画像上への注釈提示）に よる出力画像の一例を示す。

\section{6. 産業分野への応用}

現時点で最も有効にウェアラブルコンピュータの技 術が生かせるのは，まず第一に大規模な産業の末端現 場の第一線であろう。例えば, 航空機や電力プラント といった大規模な装置においては, その作業・メンテ ナンス・点検には同様に大規模な作業手順書等のマニ ュアル・ドキュメント類が必要となる。このような現 場に, ウェアラブルコンピュータを導入することによ って, 電子化されたマニュアル・ドキュメント類を臨 機応変に即座に呼び出し, 参照することができれば, 作業に要する時間と労力を大幅に削減できると期待さ れる。ボーイングや米国ホンダなどではすでに一部の 作業工程にこれらの技術を導入しているという。

特に前述のパーソナルポジショニングシステムなど を用いて, 利用者 (作業者) の現在位置・方位が分か っていることで, 計算機は作業者がどのプラントにい てどの装置を見ているのかを認識し, 作業に必要とな るオンラインドキュメントの候補一覧などを提示する ことが可能となる。情報提示には頭部装着型のウェア ラブルディスプレイを用いることでハンズフリーな作 業が可能となり，生産性の向上を見込むことができる。

また，作業等に関するエキスパートが中枢センター におり，複数の（エキスパートではない）作業者が遠 隔地にいるような状況に抒いても, 各作業者の現在位 置・方位を把握できていることで，それぞれに適切な 指示を出すことが可能となる。作業者への指示方法の 一例として, 肩に装着型のレーザポインタ付ウェアラ ブルアクティブカメラ $(\mathrm{WACL})^{15}$ を用いることがで きる。指示内容を音声とレーザポインタで伝達するこ とで, 音声コミュニケーションのみの場合と比べ, 表 現力あるコミュニケーションが実現できると期待され る。

\section{参考文献}

1) S. Mann : “An Historical Account of the Wear- 


興梠正克

Comp and WearCam Invention Developed for Applications in Personal Imaging," in Proc. of ISWC '97, 1997, p 66-73

2）映像情報メディア学会誌，小特集「ウェアラブル コンピュータ」Vol.57, No. 3, 2003

3) R.Azuma: "A survey of augmented reality" in Presence: Teleoperators and Virtual Environments, Vol. 6, No. 4, 1997, p 355-385

4) MicroOptical 社 : http ://www.micropticalcorp. $\mathrm{com} /$

5）島津製作所：http : //www.shimadzu.co.jp/hmd /

6）福本雅郎 “24 時間ニュウリョクデキマスカ？”, 理学会誌 Vol. 41, No. 2, pp. 123-126, 2000

7) Handkey 社 : http ://www.handkey.com/

8）福本雅郎, 外村佳伸：手首装着型コマンド入力機 構, 情報処理学会論文誌, Vol.40, No. 2, 1999, p 389-398

9) Takeshi Kurata, Takekazu Kato, Masakatsu Kourogi, Jung Keechul, Ken Endo : “A Functionally-Distributed Hand Tracking Method for Wearable Visual Interfaces and Its Applications “in Proc. of IAPR Workshop on Machine Vision Applications (MVA 2002), 2002, p 84-89

10) Weavy: Wearable Visual Interfaces, http :// www.is.aist.go.jp/weavy/
11）興梠正克, 蔵田武志, 坂上勝彦，村岡洋一：“パ ノラマ画像群を位置合わせに用いたライブ映像上 への注釈提示とその実時間システム”, 信学論 $(\mathrm{D}$ -II) Vol. J 84-D-II, No.10, 2001，p 2293-2301

12）興梠正克, 蔵田武志, 坂上勝彦：“ウェアラブル 拡張現実システムのための利用者のビューベース 卜位置・方位取得手法”，日本バーチャルリアリ ティ学会論文誌 vol. 7, No. 2, 2002, p 139-150

13) Masakatsu Kourogi and Takeshi Kurata: "A method of personal positioning based on sensor data fusion of wearable camera and self-contained sensors" in Proc. IEEE Conference on Multisensor Fusion and Integration for Intelligent Systems（MFI 2003), 2003, p 287-292

14) Masakatsu Kourogi and Takeshi Kurata : "Personal Positioning based on Walking Locomotion Analysis with Self-Contained Sensors and a Wearable Camera" in Proc. Int' Symp. on Mixed and Augmented Reality (ISMAR 2003), 2003, p 103-112

15）酒田信親, 加藤丈和, 興梠正克, 葛岡英明, 蔵田 武志：“レーザ搭載型ウェアラブルアクティブカ メラによる遠隔コミュニケーション支援”, 信学 技報・第 12 回複合現実感研究会, PRMU 2002172, 2003, p 19-24 